\title{
MODEL KEBIJAKAN PENANGGULANGAN KORUPSI DI UNIVERSITAS NEGERI YOGYAKARTA
}

\author{
Anang Priyanto*, M. Lies Endarwati**, Samsuri* \\ *FIS Universitas Negeri Yogyakarta \\ **FE Universitas Negeri Yogyakarta \\ email: anang_priyanto@uny.ac.id
}

\begin{abstract}
Abstrak: Model Kebijakan Penanggulangan Korupsi di Universitas Negeri Yogyakarta. Penelitian ini bertujuan untuk mengetahui kebijakan Universitas Negeri Yogyakarta dalam menanggulangi korupsi dan menemukan model kebijakan yang diinginkan Universitas Negeri Yogyakarta dalam menanggulangi korupsi. Penelitian ini adalah penelitian survei dengan pendekatan kuantitatif dan kualitatif. Sampel penelitian ditentukan secara multy stage sampling dengan teknik pengumpulan data dengan angket, dokumen dan diperkuat dengan pengumpulan data melalui Focus Group Discussion (FGD), dan validasi instrumen melalui validitas isi (content validity). Data dianalisis secara deskriptif. Hasil penelitian menunjukkan bahwa kebijakan penanggulangan korupsi di UNY tidak ada secara khusus dikeluarkan. Kebijakan yang ada mengikuti dan mempertahankan kebijakan yang lebih tinggi, yaitu dari Pemerintah. Model kebijakan penangggulangan korupsi di UNY yang digunakan adalah Model Rasional, yaitu kebijakan penanggulangan korupsi yang dikeluarkan merupakan aspirasi semua staf yang ada di unit kerja dan harus menekankan pada aspek efisiensi atas beban kerja pada unit kerja yang bersangkutan. Adapun kebijakan yang sudah ada yang berasal dari Pemerintah pusat dijadikan pedoman.
\end{abstract}

Kata kunci: kebijakan, korupsi, UNY

\begin{abstract}
Model of Policy State University of Yogyakarta in Tackling Corruption. This study aims to determine the policy of the State University of Yogyakarta in tackling corruption and find a model of the desired policy State University of Yogyakarta in tackling corruption. This research was conducted through a survey with quantitative and qualitative approaches. The research sample determined multystage sampling data collected with the questionnaires, documents and strengthened by collecting data through Focus Group Discussion (FGD), and validation of the instrument through the content validity (content validity). The data analysis technique will use descriptive quantitative analysis. The results showed that corruption prevention policy at the State University of Yogyakarta nothing specifically excluded. Existing policy and follows the policy of maintaining a higher, ie from the Government. Model alleviation policies corruption at the State University of Yogyakarta is desirable to use Rational Model, namely corruption prevention policy issued by the aspiration of all staff working in the unit and should be emphasized at the expense of the efficiency aspects of the work unit concerned. The existing policy from the central government is used as a guideline.
\end{abstract}

Keywords: policy, corruption, UNY

\section{PENDAHULUAN}

Korupsi merupakan salah satu perbuatan pidana yang akhir-akhir ini telah mewabah ke semua sendi kehidupan bangsa Indonesia. Bahaya korupsi bagi kehidupan bangsa dan Negara menjadikan segala upaya dilakukan untuk memberantasnya, baik melalui 
pembentukan dan/atau perubahan peraturan perundang-undangan maupun melalui upaya nonperaturan perundangundangan (nonlegal). Sejak berlakunya undang-undang korupsi yang telah beberapa kali mengalami perubahan dan yang terakhir dengan Undang-Undang Nomor 20 Tahun 2001 tentang Perubahan Undang-undang Nomor 31 tahun 1999 tentang Pemberantasan Tindak Pidana Korupsi, dari tahun ke tahun tindak pidana korupsi masih saja bermunculan bahkan pada akhir-akhir ini semakin marak dan dilakukan oleh tokoh-tokoh masyarakat, mulai pejabat biasa hingga pejabat tinggi di pemerintahan yang mendapat sorotan banyak pihak, seperti kasus korupsi Gayus Tambunan, kasus korupsi Nazarudin, kasus korupsi Hambalang yang banyak melibatkan banyak pihak termasuk para pejabat di pemerintahan, kasus korupsi Angelina Sondah, kasus korupsi Joko Susilo dan masih banyak lagi.

Maraknya kasus korupsi yang terjadi akhir-akhir ini seolah-olah menjadikan korupsi sebagai suatu kebiasaan. Adanya kebiasaan korupsi inilah menjadikan pemberantasan korupsi di Indonesia sulit dilakukan. Pemberantasan korupsi akan efektif bila dilakukan dengan cara mengubah kebiasaan masyarakat sejak dini dan menanamkan paradigma bahwa korupsi sebagai suatu perbuatan yang salah. Cara mengubah kebiasaan masyarakat inilah yang dapat pula disebut sebagai upaya pemberantasan korupsi di luar peraturan perundang-undangan atau dengan kata lain melalui kebijakan nonpenal.

Pemberantasan korupsi melalui kebijakan nonpenal lebih bersifat preventif guna membentuk sikap dan perilaku antikorupsi. Pembentukan sikap dan perilaku antikorupsi harus ditanamkan sejak dini kepada setiap anak bangsa ini agar terbentuk watak dan karakter bangsa yang antikorupsi. Gerakan antikorupsi harus menjadi suatu kebijakan Pemerintah agar dapat menjadi sebuah gerakan yang wajib dan dilaksanakan oleh semua pihak, baik oleh Pemerintah itu sendiri maupun semua kalangan warga masyarakat. Meski telah banyak peraturan perundangundangan antikorupsi dibentuk, upaya pemberantasan korupsi yang dilakukan melalui penanganan di luar peraturan perundang-undangan dapat dilakukan oleh pihak siapa pun, baik perorangan maupun kelompok, baik lembaga swasta maupun lembaga milik pemerintah, taidak terkecuali Universitas Negeri Yogyakarta sebagai lembaga pendidikan milik Pemerintah.

Universitas Negeri Yogyakarta (UNY) sebagai lembaga pendidikan tinggi milik pemerintah mempunyai visi, misi dan tujuan menghasilkan manusia yang memiliki ketaqwaan, kemandirian dan kecendikiaan dengan menjunjung tinggi nilai-nilai Pancasila, maka konsekuensi lulusan yang dihasilkan haruslah benarbenar menjadi manusia yang taqwa, mandiri dan cendikia. Pembentukan manusia yang taqwa, mandiri, dan cendikia harus tercermin dalam segala kegiatan akademik maupun nonakademik selama belajar di UNY. Oleh karenanya, keberhasilan pembentukan manusia yang taqwa, mandiri, dan cendikia harus merupakan tujuan utama kebijakan pimpinan UNY. Jika benar kebijakan pembentukan watak manusia yang taqwa, mandiri, dan cendikia telah dilakukan tentunya harus pula didukung kebijakan internal dalam pelayanan publik (akademik maupun nonakademik) yang tidak kalah pentingnya serta harus benarbenar bernuansa ketaqwaan, kemandirian dan kecendikiaan pula. Kebijakan yang demikian termasuk pula kebijakan dalam upaya untuk menanggulangi korupsi di UNY, karena apabila kebijakan itu berhasil menghasilkan manusiamanusia yang memiliki ketaqwaan, kemandirian, dan kecendikiaan tentunya akan memiliki watak antiperbuatan 
terlarang termasuk korupsi. Kebijakan akan berhasil dilaksanakan dengan baik manakala kebijakan itu sesuai dengan kondisi masyarakat dimana kebijakan itu diberlakukan. Demikian pula keberhasilan pelaksanaan kebijakan yang dikeluarkan haruslah merupakan aspirasi komunitas diberlakukannya kebijakan tersebut. Dengan demikian model kebijakan penanggulangan korupsi yang dikeluarkan UNY haruslah sesuai dengan kondisi dan aspirasi komunitas dimana kebijakan tersebut diberlakukan.

Dari uraian di atas dapat dikemukakan perumusan masalahnya, yaitu bagaimanakah kebijakan UNY dalam menanggulangi korupsi, dan model kebijakan apakah yang diinginkan UNY dalam menanggulangi korupsi? Dengan tujuan dapat diketahui kebijakan UNY dalam penanggulangan korupsi, dan model kebijakan yang diinginkan di UNY dalam menanggulangi korupsi.

Banyak ahli mengemukan pengertian keijakan dengan beragam, antara lain Perserikatan Bangsa-Bangsa mengartikan kebijakan sebagai pedoman untuk bertindak. James E Anderson mengartikan kebijakan sebagai perilaku dari sejumlah aktor (pejabat, kelompok, instansi pemerintah) atau serangkaian aktor dalam suatu bidang kegiatan tertentu (Solichin, 1997:2). Heclo menyatakan bahwa kebijakan lebih baik dipandang sebagai tindakan yang sengaja dilakukan atau ketidakmauan untuk bertindak secara sengaja daripada dipandang sebagai keputusan-keputusan atau tindakantindakan tertentu. Sedangkan David Easton menyatakan bahwa kebijakan terdiri dari serangkaian keputusankeputusan dan tindakan-tindakan untuk mengalokasikan nilai-nilai (Solichin, 1990:21). Derbyshire menyatakan bahwa kebijakan (policy) sebagai sekumpulan rencana kegiatan yang dimaksudkan untuk memberikan efek perbaikan terhadap kondisi-kondisi sosial ekonomi.
Lebih lanjut Derbyshire mengemukakan bahwa kebijakan merupakan produk akhir setiap pemerintahan, dalam arti merupakan kesepakatan terakhir antara eksekutif dengan wakil rakyat (Wibawa, 1994:49). Sedangkan Hofferbert sebagaimana dikutip Wibawa (1994:50) mengemukakan bahwa ada dua cara untuk memahami suatu kebijakan, yaitu pertama, mendekati suatu policy melalui substansinya (yakni rumusan-rumusan redaksi suatu kebijakan yang berisi tujuan-tujuan/'goal' apa yang hendak dicapai), dan kedua, memahami suatu policy dari proses pelaksanaannya yang membeberkan kepada kita hasil maupun dampak kebijakan tersebut baik hasil yang bersifat sementara maupun final. Rose mengemukakan bahwa kebijakan publik adalah serangkaian pilihan tindakan pemerintah (termasuk pilihan untuk tidak bertindak) guna menjawab tantangantantangan yang menyangkut kehidupan masyarakat (Wibawa, 1994:50).

Model kebijakan merupakan abstraksi dari proses pembuatan kebijakan yang penekanannya pada sesuatu hal sehingga memunculkan beberapa model, antara lain:

Model Elite. Model ini menekankan pada kebijakan yang dibuat oleh para elite politik. Kebijakan publik boleh dikatakan identik dengan perspektif elite politik. Kebijakan negara mencerminkan kehendak atau nilai-nilai sekelompok kecil orang yang berkuasa. Nilai-nilai, sikap dan pandangan elite sangat mempengaruhi kebijakan yang dihasilkan, namun tidaklah berarti kebijakan-kebijakan yang dibuat oleh para elit politik selalu tidak mementingkan kesejahteraan rakyat. Jika terjadi perubahan-perubahan kebijakan biasanya sifatnya tambal sulam ataupun trial-error yang hanya mengubah atau memperbaiki kebijakan-kebijakan sebelumnya. Dalam kondisi tertentu para elit politik tetap membutuhkan dukungan massa, sehingga mereka juga harus 
memuaskan sebagian masa tersebut dan tanggungjawab untuk menyejahterakan masyarakat dianggap tetap terletak di tangan para elite politik.

Model Kelompok. Model ini merupakan abstraksi dari proses pembuatan kebijakan yang di dalamnya beberapa kelompok kepentingan berusaha untuk mempengaruhi isi dan bentuk kebijakan secara interaktif (Wibawa, 1994:9). Pembuatan kebijakan sebagai upaya untuk menanggapi tuntutan dari berbagai kelompok kepentingan dengan cara negosiasi, bargaining, dan kompromi. Kebijakan negara merupakan kompromi atau keseimbangan yang tercapai dalam pertarungan antarkelompok yang memperjuangkan kepentingan masing-masing pada suatu waktu. Kelompok-kelompok kepentingan memiliki akses yang relatif memadai terhadap proses pembuatan kebijakan negara.

Model kelompok dapat dipergunakan untuk menganalisis proses pembuatan kebijakan maupun implementasinya. Model ini dapat digunakan untuk menelaah kelompok-kelompok apakah yang saling berkompetisi untuk mempengaruhi pembuatan kebijakan negara, dan manakah yang memiliki pengaruh yang paling kuat. Pada tingkat implementasi, kompetisi antar kelompok juga merupakan salah satu faktor yang menentukan efektivitas kebijakan dalam mencapai tujuan (Wibawa, 1994:10).

Model Rasional. Model ini berasal dari pemikiran Herbert Simon, yang menekankan bahwa inti dari perilaku administrasi adalah pada proses pengambilan keputusan secara rasional. Suatu kebijakan negara harus didasarkan pada keputusan yang sudah diperhitungkan rasionalitasnya (Wibawa, 1994:10). Model ini lebih menekankan pada aspek efisiensi maupun ekonomis. Rasionalitasnya terletak pada perbandingan antara pengorbanan dan hasil yang dicapai.
Semakin rendah nilai pengorbanan dan semakin tinggi tingkat pencapaiannya, maka suatu kebijakan dianggap baik. Sepanjang kebijakan yang ditempuh akan memberikan suatu hasil yang baik dengan sumberdaya yang paling sedikit, maka kebijakan tersebut layak untuk dilaksanakan.

Model Inkremental. Model kebijakan yang berkembang sedikit demi sedikit secara teratur. Model ini pada dasarnya merupakan kritik terhadap model rasional. Kritik tersebut menyatakan bahwa para pembuat kebijakan pada dasarnya tidak mau melakukan peninjauan secara ajeg terhadap seluruh kebijakan yang dibuatnya. Para pembuat kebijakan tidak pernah melakukan proses seperti yang dipersyaratkan oleh pendekatan rasional. Pendekatan inkremental dilakukan karena alasan (Wibawa, 1994:11): (1) para pembuat kebijakan tidak memiliki waktu, intelektualitas maupun biaya yang memadai untuk penelitian terhadap nilai-nilai sosial masyarakat yang merupakan landasan bagi perubahan tujuan kebijakan, (2) adanya kekhawatiran tentang bakal munculnya dampak yang tak diinginkan sebagai akibat dari kebijakan yang belum pernah dibuat sebelumnya, (3) adanya hasil-hasil program dari kebijakan sebelumnya yang harus dipertahankan demi suatu kepentingan, (4) menghindari adanya berbagai konflik jika harus melakukan proses negosiasi yang melelahkan bagi kebijakan baru.

Kata korupsi berasal dari bahasa latin Corruptio-Corrumpere yang artinya busuk, rusak, menggoyahkan, memutarbalik atau menyogok. Beberapa ahli mengemukakan pengertian korupsi ini dalam berbagai pendapat sesuai dengan keahliannya, namun pada intinya pendapat mereka tentang korupsi ini sama bahwa korupsi adalah perbuatan atau perilaku yang menyimpang dari mereka yang mempunyai kedudukan untuk memenuhi kepentingan pribadi yang merugikan kepentingan umum atau negara. 
Masalah korupsi merupakan masalah yang sudah lama ada dalam kehidupan masyarakat, dan masalah korupsi bukan semata-mata masalah hukum dan kebijakan penegakan hukum. Upaya penanggulangan korupsi melalui kebijakan peraturan perundang-undangan telah lama dilakukan, namun tetap saja korupsi selalu ada dan sulit untuk diberantas. Hal ini sebagaimana dikemukakan oleh Arief (1998:72) bahwa sulitnya untuk diberantas disebabkan karena masalah korupsi ini berkaitan erat dengan berbagai kompleksitas masalah lainnya, seperti misalnya sikap mental, masalah pola/sikaphidup danbudayasosial, masalah kebutuhan/tuntutan ekonomi dan struktur/sistem ekonomi, masalah lingkungan hidup/sosial dan kesenjangan sosial-ekonomi, masalah struktur/budaya politik, masalah peluang yang ada di dalam mekanisme pembangunan atau kelemahan birokrasi/prosedur administrasi (termasuk sistem pengawasan) di bidang keuangan dan pelayanan umum. Oleh karenanya masalah korupsi juga memerlukan penanganan melalui kebijakan nonperaturan perundangundangan untuk memberantasnya. Untuk itulah pemberantasan korupsi memerlukan kebijakan integral, disamping lewat kebijakan penegakan hukum atau yang oleh Arief (1998:72) disebut sebagai "penyembuhan simptomatik" juga harus diupayakan "penyembuhan kausatif" terhadap semua faktor peluang terjadinya korupsi.

\section{METODE}

Jenis penelitian ini adalah penelitian survey. Populasi penelitian ini adalah civitas akademika dan karyawan UNY dengan sampel penelitian ditentukan secara multystage sampling, yakni dengan menentukan sampel berkelompok (stratified sample) dan setiap kelompok ditentukan secara purposive sampling terlebih dahulu, dengan kriteria atau pertimbangan: (1) dosen dan karyawan sebagai pejabat pengambil keputusan di setiap unit utama UNY, (2) mahasiswa yang aktif di organisasi kemahasiswaan, (3) kemudian dilakukan snowball dengan key-informan Kapala Biro, Ketua Lembaga atau Dekan. Penentuan sampel secara multystage sampling ini dimaksudkan untuk memperoleh data yang sesuai dengan tujuan penelitian sehingga dapat ditemukan kebijakan yang digunakan dalam penanggulangan korupsi di UNY dan model kebijakan yang sesuai dalam penanggulangan korupsi di UNY.

Teknik pengumpulan data yang digunakan dengan menggunakan angket, dokumen dan diperkuat dengan pengumpulan data melalui Focus Group Discussion (FGD). Validitas instrumen (angket) dilakukan melalui validitas isi (content validity) yaitu angket didiskusikan bersama seluruh anggota tim peneliti dan dikonsultasikan kepada ahli.

Data kuantitatif akan dianalisis dengan teknikstatistik deskriptifuntukmengetahui kecenderungan-kecenderungan gambaran umum kebijakan UNY dalam penanggulangan korupsi, dan ditambah penjelasan kualitatif yang diperoleh dari wawancara dan FGD untuk mempertajam hasil analisis kuantitatif yang akan diuraikan dalam bentuk deskriptif uraian kalimat penjelasan.

\section{HASIL DAN PEMBAHASAN}

Tabel 1 menyajikan tentang kondisi responden terhadap unit kerja masingmasing.

Tabel 1. Kondisi Responden terhadap Unit Kerja

\begin{tabular}{ccc}
\hline No. & Kondisi/Keadaan Nyata & $\%$ \\
\hline 1 & $\begin{array}{l}\text { Merasa unit kerja sebagai } \\
\text { unit yang sangat penting }\end{array}$ & 45,26 \\
2 & $\begin{array}{l}\text { Merasa unit kerja sebagai } \\
\text { unit yang tidak penting }\end{array}$ & 54,74 \\
\hline \multicolumn{2}{c}{ Total } & 100,00 \\
\hline
\end{tabular}


Dari Tabel 1 dapat diketahui bahwa sebagian besar responden $(54,74 \%)$ merasa bahwa unit kerja tempat responden bekerja tidak penting sebagai bagian dari UNY secara keseluruhan.

Pengetahuan tentang korupsi dan penggolongannya disajikan pada Tabel 2 dan 3.

Tabel 2. Pengetahuan tentang Korupsi

\begin{tabular}{clr}
\hline No. & Kondisi/Keadaan Nyata & \multicolumn{1}{c}{$\%$} \\
\hline 1 & $\begin{array}{l}\text { Merasa tahu kriteria } \\
\text { perbuatan korupsi }\end{array}$ & 98,92 \\
2 & Tidak tahu kriteria korupsi & 1,08 \\
\hline \multicolumn{2}{c}{ Total } & 100,00 \\
\hline
\end{tabular}

Dari Tabel 2 dapat diketahui bahwa sebagian besar responden (98.92\%) merasa tahu kriteria korupsi.

Tabel 3. Pengetahuan Penggolongan Ko-

\begin{tabular}{clc} 
& rupsi \\
\hline No. & Kondisi/Keadaan Nyata & $\%$ \\
\hline 1 & $\begin{array}{l}\text { Tidak tahu penggolongan } \\
\text { perbuatan korupsi }\end{array}$ & 90,53 \\
2 & $\begin{array}{l}\text { Tahu penggolongan per- } \\
\text { buatan korupsi }\end{array}$ & 9,47 \\
\hline & \multicolumn{1}{c}{ Total } & 100,00 \\
\hline
\end{tabular}

Dari Tabel 3 dapat diketahui bahwa sebagian besar responden $(90,53 \%)$ tidak tahu penggolongan perbuatan korupsi.

Tabel 4 menyajikan kebijakan penanggulangan korupsi di unit kerja.

Tabel 4. Kebijakan Penanggulangan Korupsi di Unit Kerja

\begin{tabular}{clc}
\hline No. & Kondisi/Keadaan Nyata & $\%$ \\
\hline 1 & $\begin{array}{l}\text { Unit kerja ada kebijakan } \\
\text { penanggulangan korupsi }\end{array}$ & 42,10 \\
2 & $\begin{array}{l}\text { Unit kerja tidak ada kebijak- } \\
\text { an penanggulangan korupsi }\end{array}$ & 57,90 \\
\hline \multicolumn{2}{c}{ Total } & 100,00 \\
\hline
\end{tabular}

Dari Tabel 4 dapat diketahui bahwa sebagian besar responden $(57,90 \%)$ menyatakan bahwa pada unit kerjanya tidak ada kebijakan penanggulangan korupsi.

Tabel 5 keinginan unit kerja ada kebijakan penanggulangan korupsi.

Tabel 5. Keinginan Unit Kerja Ada Kebijakan Penanggulangan Korupsi

\begin{tabular}{clr}
\hline No. & \multicolumn{1}{c}{ Kondisi/Keadaan Nyata } & \multicolumn{1}{c}{$\%$} \\
\hline 1 & $\begin{array}{l}\text { Kebijakan penanggulangan } \\
\text { berupa peraturan, keputus- } \\
\text { an, surat edaran }\end{array}$ & 28,42 \\
2 & $\begin{array}{l}\text { Kebijakan dikeluarkan oleh } \\
\text { Rektor }\end{array}$ & 2,00 \\
3 & $\begin{array}{l}\text { Unit kerja tidak ada } \\
\text { kebijakan penanggulangan } \\
\text { korupsi, tetapi diserahkan } \\
\text { kepada staff masing-masing }\end{array}$ \\
& \multicolumn{1}{c}{ Tidak tahu } \\
\hline & \multicolumn{1}{c}{ Total } & 32,74 \\
\hline
\end{tabular}

Dari Tabel 5 diketahui bahwa sebagian besar responden (36,84\%) menyatakan bahwa di unit kerjanya tidak ada kebijakan penanggulangan korupsi tetapi diserahkan sepenuhnya kepada staf masing-masing untuk bertanggungjawab atas tugas dan pekerjaannya. Sebagian kecil responden (2\%) berkeinginan jika kebijakan penanggulangan korupsi dikeluarkan oleh Rektor, dan sebagian responden $(28,42 \%)$ kebijakan penanggulangan korupsi itu berupa peraturan, keputusan, surat edaran.

Dari Tabel 6 dapat diketahui bahwa sebagian responden $(30,53 \%)$ tidak tahu alasan mengapa unit kerjanya tidak ada kebijakan penanggulangan korupsi, dan sebagian besar responden $(55,78 \%)$ tidak menjawab alasan mengapa unit kerjanya tidak adakebijakan penangulangan korupsi. Sebagian kecil responden $(3,16 \%)$ menyatakan bahwa pada unit kerjanya tidak ada kebijakan penanggulangan korupsi dengan alasan pimpinan tidak berminat 
dan tidak tahu bagaimana membuat kebijakan penanggulangan korupsi.

Tabel 6. Alasan Mengapa Unit Kerja Tidak Ada Kebijakan Penangulangan Korupsi

\begin{tabular}{|c|c|c|}
\hline No. & Kondisi/Keadaan Nyata & $\%$ \\
\hline 1 & $\begin{array}{l}\text { Tidak tahu kenapa unit } \\
\text { kerja tidak ada kebijakan } \\
\text { penanggulangan korupsi }\end{array}$ & 30,53 \\
\hline 2 & $\begin{array}{l}\text { Pimpinan tidak berminat } \\
\text { membuat kebijakan } \\
\text { penanggulangan korupsi }\end{array}$ & 3,16 \\
\hline 3 & $\begin{array}{l}\text { Pimpinan tidak tahu } \\
\text { membuat kebijakan } \\
\text { penanggulangan korupsi }\end{array}$ & 3,16 \\
\hline 4 & $\begin{array}{l}\text { Pimpinan banyak disibuk- } \\
\text { kan oleh pekerjaannya }\end{array}$ & 7,37 \\
\hline \multirow[t]{2}{*}{5} & Tidak menjawab & 55,78 \\
\hline & Total & 100,00 \\
\hline
\end{tabular}

Tabel 7. Keinginan Inisiatif Isi Kebijakan

\begin{tabular}{|c|c|c|}
\hline No. & Kondisi/Keadaan Nyata & $\%$ \\
\hline \multirow[t]{6}{*}{1} & $\begin{array}{l}\text { Isi kebijakan penanggulan- } \\
\text { gan korupsi di unit kerja: }\end{array}$ & \\
\hline & a. Inisiatif pimpinan & 13,70 \\
\hline & $\begin{array}{l}\text { b. Aspirasi kelompok } \\
\text { bagian tertentu dari unit } \\
\text { kerja }\end{array}$ & 2,10 \\
\hline & $\begin{array}{l}\text { c. Aspirasi semua staf } \\
\text { yang ada di unit kerja }\end{array}$ & 11,58 \\
\hline & $\begin{array}{l}\text { d. Aspek efisiensi beban } \\
\text { kerja pada unit kerja }\end{array}$ & 13,68 \\
\hline & $\begin{array}{l}\text { e. Kebijakan yang sudah } \\
\text { ada dengan tidak mela- } \\
\text { kukan perubahan }\end{array}$ & 24,21 \\
\hline \multirow[t]{2}{*}{2} & Tidak tahu & 34,73 \\
\hline & Total & 100,00 \\
\hline
\end{tabular}

Dari Tabel 7 dapat diketahui bahwa sebagian besar responden $(34,73 \%)$ tidak tahu atau tidak menjawab keinginan inisiatif isi kebijakan penanggulangan korupsi untuk unit kerjanya. Sebagian responden $\quad(24,21 \%)$ menginginkan inisiatif isi kebijakan penanggulangan korupsi dikembalikan kepada kebijakan yang sudah ada dengan tidak melakukan perubahan. Sebagian kecil responden $(2,10 \%)$ menginginkan isi kebijakan penanggulangan korupsi merupakan aspirasi kelompok bagian tertentu yang ada di unit kerja masing-masing.

Tabel 8. Perlunya Penerapan Kebijakan Penanggulangan Korupsi

\begin{tabular}{clc}
\hline No. & Kondisi/Keadaan Nyata & $\%$ \\
\hline 1 & Diterapkannya kebijakan \\
& penanggulangan korupsi di \\
& \\
& unit kerja sebaiknya:
\end{tabular}

a. Menekankan aspek 41,05 efisiensi dan ekonomis

b. Merupakan hasil pemikiran pejabat berupa peningkatan kualitas pekerjaan dan kesejahteraan pegawai

c. Berupa hasil kesepa8,42 katan bersama seluruh pegawai

d. Mengikuti dan memper- $\quad 26,31$ tahankan kebijakan yang sudah ada yang lebih tinggi

\begin{tabular}{rr}
2 Tidak tahu & 11,59 \\
\hline Total & 100,00 \\
\hline
\end{tabular}

Dari Tabel 8 dapat diketahui bahwa sebagian besar responden $(41,05 \%)$ perlunya penerapan kebijakan penanggulangan korupsi dengan menekankan pada aspek efisiensi dan ekonomis. Sebagian kecil $(8,42 \%)$ menginginkan perlunya penerapan kebijakan penanggulangan korupsi sebagai hasil kesepakatan bersama seluruh pegawai.

Data harapan atau keinginan dan saran responden atas kebijakan penanggulangan korupsi di UNY dari angket terbuka, antara lain: (a) perlu disusun pedoman terkait kebijakan 
penanggulangan korupsi, dan bentuk atau format diserahkan kepada yang lebih kompeten; (b) memberi kepercayaan bagi Sumber Daya Manusia yang ditunjuk dalam bidang keuangan dan sarana prasarana; (c) ada peraturan atau rambu-rambu yang dikeluarkan UNY sebagai pedoman kerja yang baku, sehingga dapat mengurangi resiko terjadinya penyalahgunaan wewenang atau korupsi di unit-unit yang langsung di bidang pekerjaan pengadaan, keuangan dan lain-lain; (d) supaya diterapkan sesuuai undang-undang tindak pidana korupsi; (e) demi keamanann dan kenyamanan bekerja, kebijakan perlu diimbangi dengan sosialisasi yang terus menerus dan berkelanjutan, sanksi yang tegas dan tidak pilih-pilih terhadap pelaku disertai dengan peningkatan kualitas kerja dan kualitas kesejahteraan; (f) rotasi rutin pegawai 4 tahunan harus diterapkan secara konsisten; (g) meningkatkan transparansi keuangan, pengawasan dan pembinaan; (h) perlu monitoring rutin bagi para pemegang uang, perlu penjelasan tentang korupsi, dan perlu koordinasi antar pejabat dan staf; (i) melakukan monitoring terhadap setiap jenis pengeluaran yang dilakukan oleh UNY; (j) dibentuk tim satgas antikorupsi, dan memberlakukan zona bebas KKN; (k) menciptakan system pelayanan yang dapat mengakomodir peraturan antikorupsi; (l) Tim Satuan Pengawas Internal (SPI) selalu mengadakan ceking secara rutin setiap triwulanan untuk mencegah adanya korupsi di UNY; (m) perlu diterbitkan peraturan pencegahan korupsi di UNY sebagai pedoman bagi semua pegawai; (n) efektivitas implementasi kegiatan yang menggunakan asset lembaga yang bersih dari unsur korupsi di semua unit kerja, penerapan dan peneladanan bersih korupsi diawali pimpinan paling tinggi di masing-masing unit kerja; penanaman, pemahaman dan penerapan sikap mental religius yang kontinyu dengan frekuensi yang tinggi di UNY.
Data yang diperoleh dari Focus Group Discussion (FGD), antara lain: (a) keterbatasaninformasi keuangan, sehingga sulit untuk memberikan komentar; (b) Pejabat paling atas seharusnya mengambil peran dalam kebijakan antikorupsi; (c) Mestinya sistemnya transparan sehingga pihak lain bisa mengontrol; (d) potensi korupsi ada pada tahapan pencairan anggaran, bukan pada pengusulannya; (e) belum ada kebijakan antikorupsi yang jelas, hanya caranya saja yang muncul; (f) korupsi tidak selalu masalah uang, tetapi kegiatan yang menimbulkan perbedaan antara hari dan kegiatan yang dilakukan; (g) lebih baik jika dibuat peraturan turunan yang ada di lingkungan sendiri di luar peraturan pusat yang sudah standar; (h) penanggulangan korupsi sudah ada di UNY tetapi kurang sosialisasi dan implementasi; (i) korupsi juga bisa terjadi karena system yang kurang mendukung; (j) setiap fakultas memiliki kebijakan pelaporan penggunaan keuangan yang berbeda; (k) kebijakan penanggulangan korupsi sebaiknya dijabarkan dan dibuat oleh pemimpin tertinggi yaitu rektor.

Data dari dokumen yang berhubungan dengan kebijakan penanggulangan korupsi di UNY berupa Peraturan Pemerintah Nomor 53 Tahun 2010 tentang Disiplin Pegawai Negeri Sipil dan Peraturan Menteri Pendayagunaan Aparatur Negara Nomor: PER/87/M.PAN/ 8/2005 tentang Pedoman Peningkatan Pelaksanaan Efisiensi, Penghematan dan Disiplin Kerja.

Sebagian besar responden $(98,92 \%)$ merasa mengetahui arti korupsi, namun kriteria perbuatan yang tergolong korupsi tidak tahu secara lengkap (90,53\%), mereka mengganggap korupsi hanya sebatas per-buatan yang menguntungkan diri sendiri atau orang lain atau suatu korporasi, bahkan korupsi diartikan secara luas tidak hanya sebatas masalah uang (lihat Tabel 2 dan Tabel 3) serta data harapan atau keinginan dan saran responden serta hasil FGD). Sebagian besar 
responden $(54,74 \%)$ menganggap bahwa unit kerja tempatnya bekerja merupakan unit kerja yang tidak penting (lihat Tabel 1). Hal ini menunjukkan bahwa responden belum memahami arti sebuah unit kerja dalam sistem tata kelola suatu organisasi atau lembaga atau instansi seperti UNY. Anggapan demikian juga menunjukkan tingkat pemahaman yang parsial dan tidak sistemik atas sebuah unit kerja dalam suatu tata kelola kelembagaan. Pendapat ini dapat berdampak pada pola kerja yang dilakukan yang dapat mengakibatkan persaingan kerja yang tidak sehat dan saling menjatuhkan.

\section{Kebijakan Penanggulangan Korupsi di UNY}

Di UNY tidak ada kebijakan yang khusus dikeluarkan oleh Pimpinan UNY untuk menanggulangi korupsi (lihat Tabel 4). Selama ini penanggulangan korupsi sebatas melaksanakan peraturan yang sudah ada dari Pemerintah yang berhubungan dengan persoalan disiplin kerja, seperti Peraturan Pemerintah Nomor 53 Tahun 2010 tentang Disipiln Pegawai Negeri Sipil dan Peraturan Menteri Pendayagunaan Aparatur Negara Nomor: PER/87/M.PAN/8/2005 tentang Pedoman Peningkatan Pelaksanaan Efisiensi, Penghematan dan Disiplin Kerja.

Peraturan Menteri Pendayagunaan Aparatur Negara Nomor: PER/87/M. PAN/8/2005 menuntut agar pegawai negeri di lingkungan instansi pemerintah seperti UNY untuk melakukan perubahan pola pikir dan perilaku serta harus memahami kondisi objektif dan perubahan lingkungan Negara dan masyarakat, serta harus mampu menjadi perekat pesatuan bangsa, alat mewujudkan kerukunan sosial, kebersamaan, dan kesetaraan dalam kehidupan bermasyarakat, berbangsa dan bernegara serta dalam menyelenggarakan tugasnya bertanggungjawab mewujudkan kepemerintahan yang baik (goodgovernance) dan kepemerintahan yang bersih (clean governance). Demikian juga dalam melaksanakan tanggungjawabnya wajib melakuan perubahan sikap, tindakan, dan perilaku ke arah budaya kerja efisien, hemat, disiplin tinggi, dan antikorupsi, dan nepotisme (KKN), dan secara sistematis dan berkelanjutan berupaya menjadi panutan dan tauladan dalam lingkungan masyarakat.

Peraturan Menteri Pendayagunaan Aparatur Negara Nomor: PER/87/M. PAN/8/2005 ini digunakan sebagai pedoman bagi pegawai negeri terutama pimpinan instansi pemerintah atau unit kerja untuk acuan dalam menyusun pedoman teknis dalam upaya meningkatkan efisiensi, penghematan dan kedisiplinan kerja, dengan sistem pengawasan dan pengendalian yang diharuskan memperhatikan prinsipprinsip: (a) mengaktifkan sistem pengawasan internal yang lebih obyektif, transparan, dan institusional, (b) partisipatif, dengan melibatkan berbagai pihak yang terkait, (c) berorientasi pembinaan dalam rangka perbaikan sistem, metode, dan perubahan tingkahlaku Aparatur Pemerintah menuju kepada sasaran yang diharapkan, (d) brusaha lebih banyak menggunakan pendekatan reward daripada punishment. Penjatuhan hukuman diberikan dalam kaitan mendidik (secara edukatif).

Disamping itu melalui penerapan Peraturan Pemerintah Nomor 53 Tahun 2010 tentang Disiplin Pegawai Negeri Sipil yang diharapkan dalam rangka mewujudkan pegawai negeri sipil yang handal, profesional, dan bermoral sebagai penyelenggara pemerintahan yang menerapkan prinsip-prinsip kepemerintahan yang baik (good governance), maka pegawai negeri sipil sebagai unsur aparatur negara dituntut untuk setia kepada Pancasila, Undang-Undang Dasar Negara Republik Indonesia Tahun 1945, Negara Kesatuan Republik Indonesia, dan Pemerintah, bersikap disiplin, jujur, 
adil, transparan, dan akuntabel dalam melaksanakan tugas.

Kebijakan pencegahan munculnya korupsi di UNY mengikuti dan mempertahankan kebijakan yang sudah ada yang berasal dari pejabat lebih tinggi, dalam hal ini segala kebijakan/peraturan perundang-undangan yang dikeluarkan oleh Pemerintah Pusat. Oleh karenanya, kebijakan yang dikeluarkan pimpinan UNY selalu mendasarkan pada kebijakan dari Pemerintah, terutama Peraturan Menteri Pendayagunaan Aparatur Negara Nomor: PER/87/M.PAN/8/2005 dan Peraturan Pemeintah Nomor 53 Tahun 2010 tentang Disiplin Pegawai Negeri Sipil.

\section{Model Kebijakan Penanggulangan Korupsi yang Diinginkan di UNY}

Model kebijakan penanggulangan korupsi yang diinginkan dilakukan di UNY berdasarkan hasil penelitian di atas adalah Model Rasional. Hal ini berdasar atas kondisi riel, aspirasi dan keinginan responden yang sesuai dengan tugas dan wewenangnya di unit kerja masingmasing sebagai data penelitian, dan dari data yang diperoleh ditunjukkan bahwa kebijakan penanggulangan korupsi yang dikeluarkan, isinya diinginkan merupakan aspirasi semua staf yang ada di unit kerja dan harus menekankan pada aspek efesiensi atas beban kerja pada unit kerja yang bersangkutan, serta sebaiknya dibuat sebagai turunan dari kebijakan yang sudah ada yang berasal dari Pemerintah pusat. Kebijakan penanggulangan korupsi juga diharapkan sebagai pedoman bagi semua pegawai untuk melaksanakan tugas masing-masing, serta sebaiknya dijabarkan dan dibuat oleh pemimpin tertinggi yaitu rektor.

Diterapkannya Peraturan Menteri Pendayagunaan Aparatur Negara Nomor: PER/87/M.PAN/8/2005 tentang Pedoman Peningkatan Pelaksanaan Efisiensi, Penghematan dan Disiplin Kerja didukung dengan adanya harapan atau keinginan segenap komunitas UNY akan adanya transparansi keuangan dan pengawasan yang baik dalam penggunaannya, serta perlu adanya pedoman teknis atau panduan kerja yang baku, sehingga dapat mengurangi resiko terjadinya penyalahgunaan wewenang atau korupsi di unit-unit kerja masing-masing agar ada keamanan dan kenyamanan dalam bekerja, menunjukkan bahwa kebijakan penanggulangan korupsi yang diinginkan di UNY adalah kebijakan penanggulangan korupsi Model Rasional. Demikian pula dukungan diterapkannya Peraturan Pemerintah Nomor 53 Tahun 2010 tentang Disiplin Pegawai Negeri Sipil yang berisi kewajiban dan larangan bagi Pegawai Negeri Sipil menguatkan alasan harapan atau keinginan digunakannya Model Rasional dalam mengeluarkan kebijakan penanggulangan korupsi di UNY.

Model Rasional menekankan pada aspek efisiensi maupun ekonomis. Tuntutan Sumber Daya Manusia Aparatur Pemerintah dalam melaksanakan tanggungjawabnya untuk wajib melakukan perubahan sikap, tindakan, dan perilaku ke arah budaya kerja efisien, hemat, disiplin tinggi, dan antikorupsi, kolusi, dan nepotisme (KKN) serta berupaya secara sistematis dan berkelanjutan menjadi panutan dan teladan dalam lingkungan masyarakat sebagaimana diatur dalam Pasal 3 Peraturan Menteri Pendayagunaan Aparatur Negara Nomor: PER/87/M.PAN/ 8/2005 lebih menguatkan kesimpulan bahwa model kebijakan penanggulangan korupsi yang diinginkan di UNY adalah Model Rasional.

Model rasional sebagai model kebijakan yang diinginkan untuk diterapkan di UNY dalam upaya menanggulangi korupsi merupakan kebijakan yang lebih aspiratif untuk mencapai tujuan akhir yang diinginkan dari kebijakan tersebut, sehingga dapat mendatangkan hasil yang memuaskan sesuai keinginan komunitas UNY. 


\section{SIMPULAN}

Kebijakan penanggulangan korupsi di UNY tidak ada secara khusus dikeluarkan, dan kebijakan yang ada selama ini mengikuti dan mempertahankan kebijakan yang sudah ada yang lebih tinggi dari Pemerintah. Model kebijakan penangggulangan korupsi yang diinginkan di UNY adalah Model Rasional, yaitu model kebijakan yang yang menekankan pada proses pengambilan keputusan secara rasional atau yang sudah diperhitungkan rasionalitasnya dan lebih menekankan pada aspek efisiensi maupun ekonomis.

Konsekuensi dari hasil penelitian perlu dilakukan sosialisasi kepada seluruh pegawai UNY tentang korupsi, agar mereka mendapat pengetahuan dan pemahaman tentang korupsi yang benar, dan segera dikeluarkan kebijakan penanggulangan korupsi yang lebih khusus oleh pimpinan UNY sesuai model kebijakan yang tepat dan diinginkan oleh seluruh komunitas UNY serta sesuai dengan visi dan misi UNY agar dalam melaksanakan tugas dan tanggung jawab seluruh pegawai mempunyai pedoman kerja yang jelas terhindar dari perbuatan korupsi serta segera dilakukan uji coba model kebijakan penanggulangan korupsi yang tepat diberlakukan di UNY agar diperoleh efektivitas penggunaan model kebijakan tersebut untuk membawa manfaat bagi kemajuan UNY

Atas terselesaikannya penelitian tersebut tak lupa diucapkan banyak terima kasih kepada segenap pejabat di UNY dan berbagai pihak yang telah membantu dalam pelaksanaan penelitian ini serta memberi masukan atas data yang diperlukan dalam pelaksanaan penelitian ini.

\section{DAFTAR PUSTAKA}

Arief, B.N. (1996). Bunga Rampai Kebijakan Hukum Pidana. Bandung: Citra Aditya Bakti.

Arief, B.N. (1998). Beberapa Aspek Kebijakan Penegakan dan Pengembangan Hukum Pidana. Bandung: Citra Aditya Bakti.

Arikunto, S. (1992). Prosedur Penelitian Suatu Pendekatan Praktik. Jakarta: Rineka Cipta.

Solichin, A.W. (1990). Analisis Kebijaksanaan Negara. Jakarta: Rineka Cipta.

Solichin, A.W. (1997). Analisis Kebijaksanaan dari Formulasi ke Implementasi Kebijaksanaan Negara. Jakarta: Bumi Aksara.

Wibawa, S. (1994). Kebijakan Publik Proses dan Analisis. Jakarta: Intermedia. 